\title{
Studies on the flow of zinc, cobalt, copper and manganese along the digestive tract of sheep given fresh perennial ryegrass, or white or red clover
}

\author{
By N. D. GRACE \\ Applied Biochemistry Division, DSIR, Palmerston North, New Zealand \\ (Received 12 August 1974-Accepted 29 Fanuary 1975)
}

\begin{abstract}
1. Sheep fitted with a rumen fistula and either a re-entrant cannula at the proximal duodenum or a re-entrant cannula at the terminal ileum were given twice daily $480-520 \mathrm{~g}$ dry matter as fresh perennial ryegrass, or white or red clover. Flows of digesta were corrected to $100 \%$ recovery of chromic oxide.

2. The quantities $(\mathrm{g} / 24 \mathrm{~h})$ of zinc and cobalt leaving the stomach were significantly greater than those in the food. No significant change was found in the quantities of copper and manganese. Significantly smaller quantities of Co (all three diets) and $\mathrm{Zn}$ (all diets except red clover) left the small intestine than those which entered this region. No significant differences in the quantities of $\mathrm{Cu}$ and $\mathrm{Mn}$ entering and leaving the small intestine were found. Significantly smaller quantities of $\mathrm{Zn}, \mathrm{Co}, \mathrm{Cu}$ and $\mathrm{Mn}$ were excreted in the faeces than entered the large intestine.

3. From the flow results it was determined that there was a significant net secretion of $\mathrm{Zn}_{\mathbf{n}}$ and $\mathrm{Co}$ in the stomach, and a significant net absorption of $\mathrm{Zn}$ (except with the red-clover diet) and $\mathrm{Co}$ from the small intestine, and of $\mathrm{Zn}, \mathrm{Co}, \mathrm{Cu}$ and $\mathrm{Mn}$ from the large intestine.
\end{abstract}

The importance of trace elements, and their characteristic signs of deficiency in the ruminant, are well documented but more information is needed about their metabolism (Underwood, 1971). Although it is known that the apparent availability of many micro-elements is low and that dietary factors can influence the absorption of some, there is not sufficient information about their passage along the digestive tract and their sites of absorption or secretion.

In this study the flows of zinc, cobalt, copper and manganese along the digestive tract were determined using sheep equipped with re-entrant cannulas. Values obtained for flows were corrected to mean $24 \mathrm{~h}$ flows (MacRae \& Armstrong, 1969) to determine the quantities of the micro-elements entering and leaving the stomach, small and large intestine.

\section{EXPERIMENTAL}

Sheep

Eight castrated male Romney Marsh sheep ( $1 \cdot 5-2 \cdot 5$ years old) weighing $37-42 \mathrm{~kg}$ were equipped with rumen fistulas; four of these animals were fitted with a re-entrant cannula at the proximal duodenum ( $50 \mathrm{~mm}$ beyond the pylorus) and the other four were fitted with a re-entrant cannula at the terminal ileum $(400-500 \mathrm{~mm}$ from the ileo-caecal valve) (Brown, Armstrong \& MacRae, 1968). All sheep were housed indoors in wooden metabolism crates fitted with stainless-steel grate floors, wooden 
food boxes and plastic water buckets. Distilled water was freely available for drinking. Care was taken during the experiments to avoid contamination of samples with microelements from the surroundings, and distilled water was used for rinsing the food and water containers.

\section{Diet and feeding procedure}

The three pasture species studied were: Lolium perenne L., 'Grasslands Ruanui' perennial ryegrass; Trifolium repens L., 'Grasslands 4700' white clover; Trifolium pratense L., 'Grasslands Hamua' red clover. Pure stands had been established for several years and were maintained by annual dressings of $200 \mathrm{~kg}$ potassium superphosphate/ha. The perennial ryegrass received, in addition, $200 \mathrm{~kg}$ ammonium sulphate/ha. Weeds in the clover were controlled using 'Tropotox' MCPB (May and Baker Ltd, Dagenham, Essex) at the rate of 3-4 1/ha and the clover in the perennial ryegrass was controlled using 'Gramoxone' 24-D (ICI (New Zealand) Ltd, Auckland, New Zealand), $\mathrm{r} \cdot 5 \mathrm{l} / \mathrm{h}$. During the experiment the perennial ryegrass and white clover were cut at a height of $80-140 \mathrm{~mm}$ and the red clover was cut at a height of $200-300 \mathrm{~mm}$. Harvesting was at 08.00 hours daily and after a thorough mixing, a sample was taken for immediate determination of dry matter (Ulyatt \& MacRae, 1974) to estimate the amount of fresh pasture required to give dry-matter intakes ranging from 480 to $520 \mathrm{~g} / \mathrm{d}$. The calculated amount of fresh food was weighed, divided into two equal portions and each portion was given at 09.00 and 16.30 hours. A second sample was taken and dried at $105^{\circ}$ for $24 \mathrm{~h}$ to determine accurately the dry-matter content, and the dry-matter intake of the sheep.

The experiment lasted 9 months: the perennial ryegrass was harvested during April and May, the white clover during June and July and the red clover during October and November.

\section{Experimental design and sampling procedures}

A summary of the experimental design in terms of diet fed, numbers of sheep, collection dates and number of samples collected is shown in Table $\mathrm{I}$.

After a preliminary feeding period of $3-4$ weeks there was a $9 \mathrm{~d}$ balance period in which collections of urine and faeces were made. The daily output of urine was recorded and portions ( $10 \mathrm{ml} / \mathrm{l}$ ) were bulked to give one sample/sheep per collection period. The daily faecal output was measured and samples were taken for dry-matter determinations and for chemical analysis. For $3 \mathrm{~d}$ periods all daily faecal samples were bulked to give three faecal samples/sheep per collection period. The fresh pasture was sampled throughout the experiment; samples for each species were bulked every $3 \mathrm{~d}$, to give three samples for the $9 \mathrm{~d}$ balance period and six samples for the subsequent $2-3$ weeks of $24 \mathrm{~h}$ collection periods, that is, a total of nine samples/diet.

In the 2 or 3 weeks after the $9 \mathrm{~d}$ balance period two, three or four $24 \mathrm{~h}$ collections/ sheep (i.e. twelve-sixteen collections/diet) of duodenal and ileal digesta were made using the techniques of MacRae \& Armstrong (1969) and Ulyatt \& MacRae (1974). The re-entrant cannulas were disconnected and all the digesta leaving the proximal cannula were collected, weighed and sampled about every $2 \mathrm{~h}$ (Beever, Thomson, 
Vol. 34

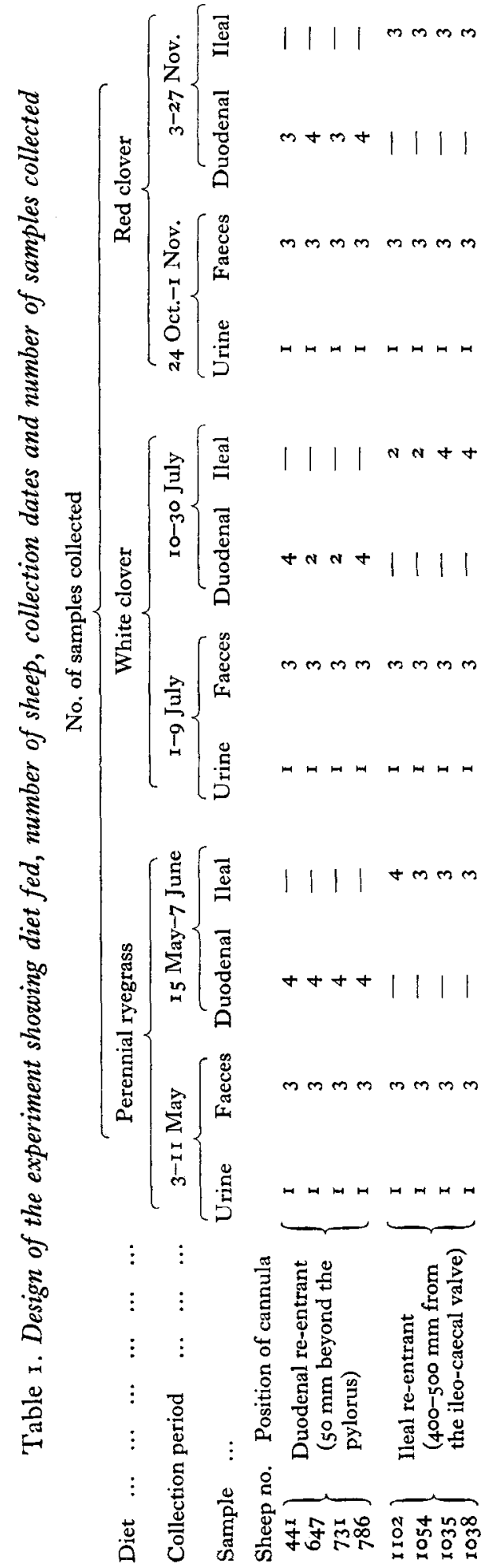


Pfeffer \& Armstrong, I971). The amount of sample taken for analysis was 14 and 21 \% of the duodenal and ileal digesta respectively. After sampling, material collected in the preliminary feeding period was added to the remaining digesta to make them up to the original collected weight. The digesta were then warmed to $40^{\circ}$ and re-introduced into the distal cannula at a rate approximating to the flow of digesta from the proximal cannula. All samples of food, digesta, faeces and urine were stored at $-10^{\circ}$. Chromic oxide, which was used as an inert marker to correct the values obtained for $24 \mathrm{~h}$ flow of digesta to mean $24 \mathrm{~h}$ flows (MacRae \& Armstrong, 1969), was placed in the rumen, through the rumen fistula, as $\mathrm{Cr}_{2} \mathrm{O}_{3}$-impregnated paper pellets $(3 \mathrm{~g} / \mathrm{sheep})$ twice daily, prior to feeding.

\section{Analytical methods}

Samples of food, duodenal and ileal digesta and faeces were freeze-dried and ground, using a porcelain mortar and pestle, before analysis. Sub-samples ( $\mathrm{g}$ for $\mathrm{Zn}$, $\mathrm{Cu}$ and $\mathrm{Mn}$ determinations; $5 \mathrm{~g}$ for Co determination) were ashed at $500^{\circ}$ for $6-8 \mathrm{~h}$, treated with $\mathrm{I}_{5} \mathrm{M}-\mathrm{HNO}_{3}$ and re-ashed if necessary to destroy all organic matter, before extracting the ash using $10 \mathrm{ml} 2 \mathrm{M}-\mathrm{HCl}$. The urine samples $(25 \mathrm{ml}$ for $\mathrm{Zn}, \mathrm{Cu}$ and $\mathrm{Mn}$ determinations; $60 \mathrm{ml}$ for Co determination) were dried and digested using an acid mixture (16 $\mathrm{M}-\mathrm{HNO}_{3}-\mathrm{I} 8 \mathrm{M}-\mathrm{H}_{2} \mathrm{SO}_{4}-9 \mathrm{M}-\mathrm{HClO}_{4}$ (го:2:4, by vol.)). Analytical grade chemicals were used to prepare all reagents and all glassware was acid-washed and thoroughly rinsed in glass-distilled water. All samples were diluted, and $\mathrm{Zn}, \mathrm{Cu}$ and Co contents were determined by atomic absorption spectrophotometry. In the instance of $\mathrm{Co}$, the method of additions (Perkin-Elmer, 1971) was used to eliminate matrix effects resulting from the high concentration of solids in the samples. As the urine samples contained high levels of $\mathrm{K}, \mathrm{KCl}$ was added to the standards used in the determination of micro-element contents for the urine. The chromium content of samples was determined by atomic absorption spectrophotometry using the method of Williams, David \& Iismaa (1962). The titanium content of the pasture samples, which indicated the amount of soil contamination (Field \& Purves, r964), was determined by X-ray fluorescence using the method described by Healy (1968).

\section{Statistical analysis}

All results from each sheep, for each collection period, were used to calculate the mean flow rates of micro-elements with their standard errors (Table 3 ) for each diet, at each sampling site. The significance of the difference between the flow of a micro-element entering and leaving a region of the digestive tract was determined using a $t$ test.

\section{RESULTS}

The average micro-element composition for the pasture species used in this study are shown in Table 2.

The levels of $\mathrm{Zn}, \mathrm{Co}$ and $\mathrm{Cu}$ were similar for all plants but the $\mathrm{Mn}$ content of the grass was about twice that for the clovers. The $\mathrm{Cr}_{2} \mathrm{O}_{3}$-impregnated paper contained $(\mu \mathrm{g} / \mathrm{g}) 8 \mathrm{Zn}, 0.072 \mathrm{Co}, \mathrm{r} \cdot 9 \mathrm{Cu}, \mathrm{I} 8 \mathrm{Mn}$. From Ti determinations the extent of the soil 
Table 2. The micro-element composition $(\mathrm{mg} / \mathrm{kg})$ for fresh perennial ryegrass, white clover and red clover given to sheep

(Mean values for nine samples/diet, three samples taken during the $9 \mathrm{~d}$ balance period and six samples taken during the 2-3 week period of $24 \mathrm{~h}$ digesta collection)

$\begin{array}{lcccc} & \text { Zinc } & \text { Cobalt } & \text { Copper } & \text { Manganese } \\ \text { Perennial ryegrass } & 25 & 0.41 & 8 \cdot 8 & 75 \\ \text { White clover } & 28 & 0.53 & 9 \cdot 1 & 34 \\ \text { Red clover } & 3 \mathrm{I} & 0.48 & \text { II.0 } & 39\end{array}$

contamination for the perennial ryegrass, white clover and red clover was estimated to be $0.8, \mathrm{I} \cdot 4$ and $0.25 \%$ respectively.

For perennial ryegrass, white clover and red clover respectively the mean ( $\pm \mathrm{SE}$ ) daily dry-matter intakes ( $\mathrm{g} / 24 \mathrm{~h}$ ) were 480 (I I ), 489 (I 5$), 520$ (I3); the corrected mean ( $\pm \mathrm{SE}) 24 \mathrm{~h}$ dry-matter flows $(\mathrm{g} / 24 \mathrm{~h}$ ) were: at the duodenal cannulas, $293(20), 276$ (12), 356 ( I9); at the ileal cannulas, I8I (7), 167 (7), 259 (I2); the mean ( \pm SE) quantities of dry matter $(\mathrm{g} / 24 \mathrm{~h})$ excreted in the faeces of the sheep given these diets were: I 8 ( 13.2$), 92(6 \cdot 5), I_{2} 7(\mathrm{II} \cdot 2)$. The recoveries of $\mathrm{Cr}_{2} \mathrm{O}_{3}$ in the faeces, for all sheep, irrespective of diet, ranged from 97 to $102 \%$.

From the dry-matter flows along the digestive tract and the micro-element concentration in the digesta and faeces, the flows of these elements along the digestive tract were determined. The $\mathrm{Zn}, \mathrm{Co}, \mathrm{Cu}$ and $\mathrm{Mn}$ contents for the diets, for digesta entering and leaving the small intestine, and the amounts excreted in the faeces are shown in Table 3 .

For all sheep, irrespective of diet, the quantities of $\mathrm{Zn}$ and Co leaving the stomach region were significantly greater $(P<0.05)$ than those in the food. There were no significant differences between the quantities of $\mathrm{Cu}$ and of $\mathrm{Mn}$ entering and leaving the stomach region.

For all diets the quantities of Co entering the small intestine were significantly greater $(P<0.05)$ than those leaving the small intestine, but there were no significant differences between the quantities of $\mathrm{Cu}$ or $\mathrm{Mn}$ entering and leaving the small intestine. For sheep fed on red clover there was also no difference between the quantities of $\mathrm{Zn}$ entering and leaving the small intestine. However, for sheep fed on perennial ryegrass and white clover the quantities of $\mathrm{Zn}$ entering the small intestine were significantly greater $(P<0.05)$ than those leaving the small intestine. The amounts of $\mathrm{Zn}, \mathrm{Co}, \mathrm{Cu}$ and $\mathrm{Mn}$ excreted in the faeces were significantly less $(P<0.05)$ than those leaving the small intestine.

The sites of net absorption and net secretion of $\mathrm{Zn}, \mathrm{Co}, \mathrm{Cu}$ and $\mathrm{Mn}$, as determined from their flows along the digestive tract, are shown in Fig. I.

There was a net secretion of $\mathrm{Zn}$ and $\mathrm{Co}$ into the stomach region and a net absorption of $\mathrm{Zn}, \mathrm{Co}, \mathrm{Cu}$ and $\mathrm{Mn}$ from the large intestine for all sheep, irrespective of diet. A small net absorption of $\mathrm{Zn}$ from the small intestine was found for sheep given perennial ryegrass, and for those given white clover; there was a greater net absorption of Co from this region for all sheep. 
.

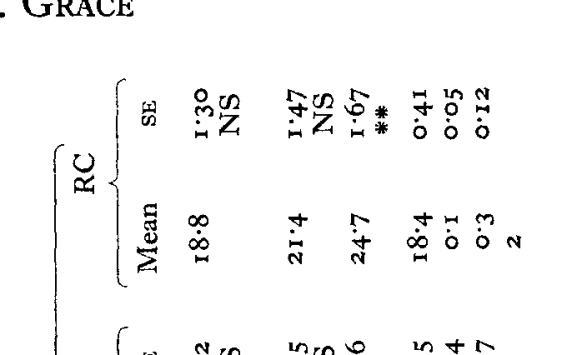

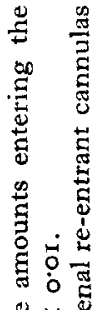

ड

$\approx$

ह

ปे

\&

窇.

胥

. ำ 는

ङ

จ

के

.

\&

ฐू้

हो

ละ हิ

ป స.

वे ही

है क

जै के झ

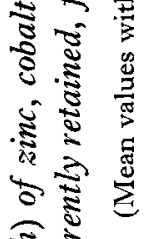

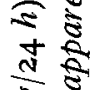

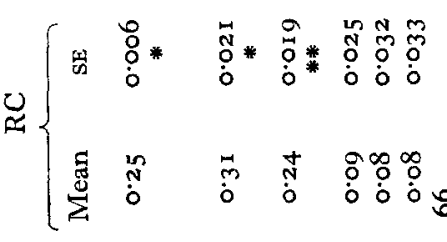

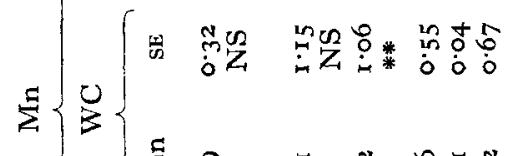

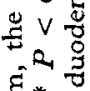

$\{0$

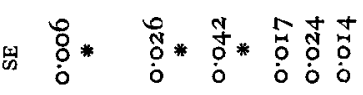

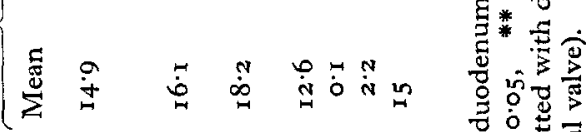

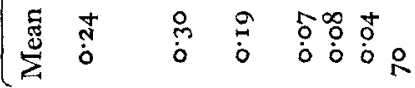

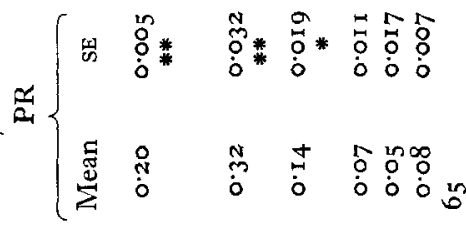

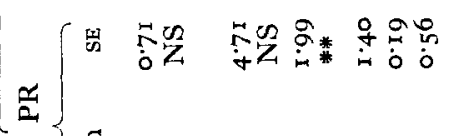

O $V$ 焉

敌造

*

焉焉要导

焉

究至

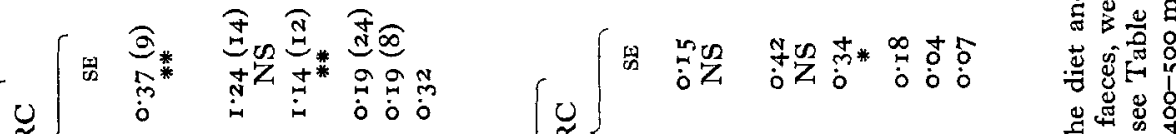

焉总总

.

욜

范苾

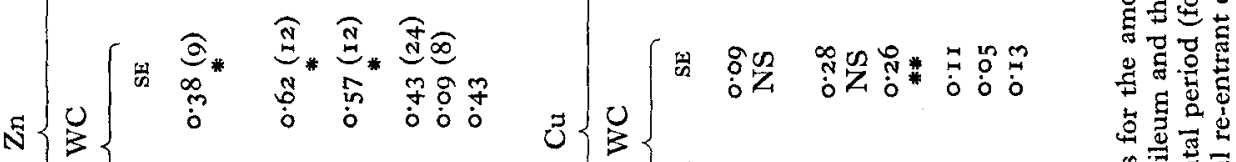

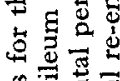

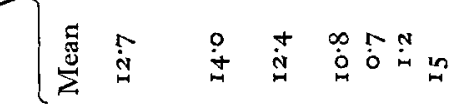

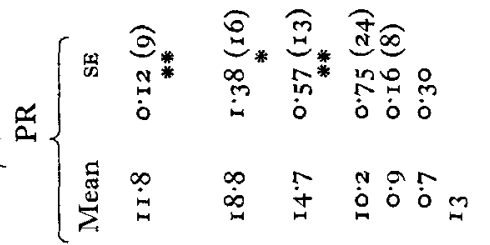

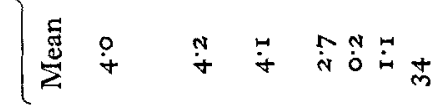

电焉

क 5

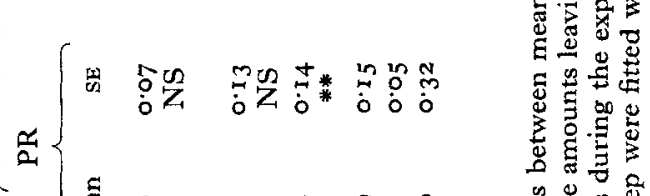

过苋造

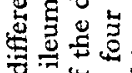

च

을

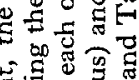

논

요

E्ञ

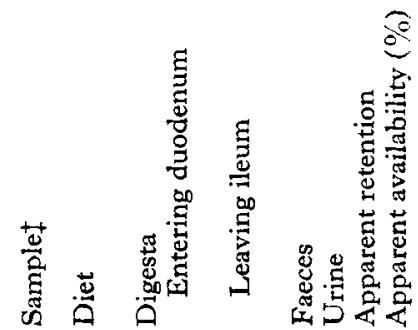

i

$\frac{0}{5} \cong$

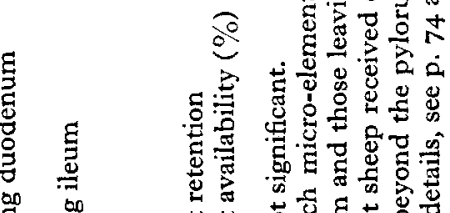

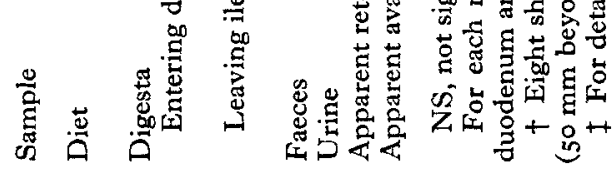



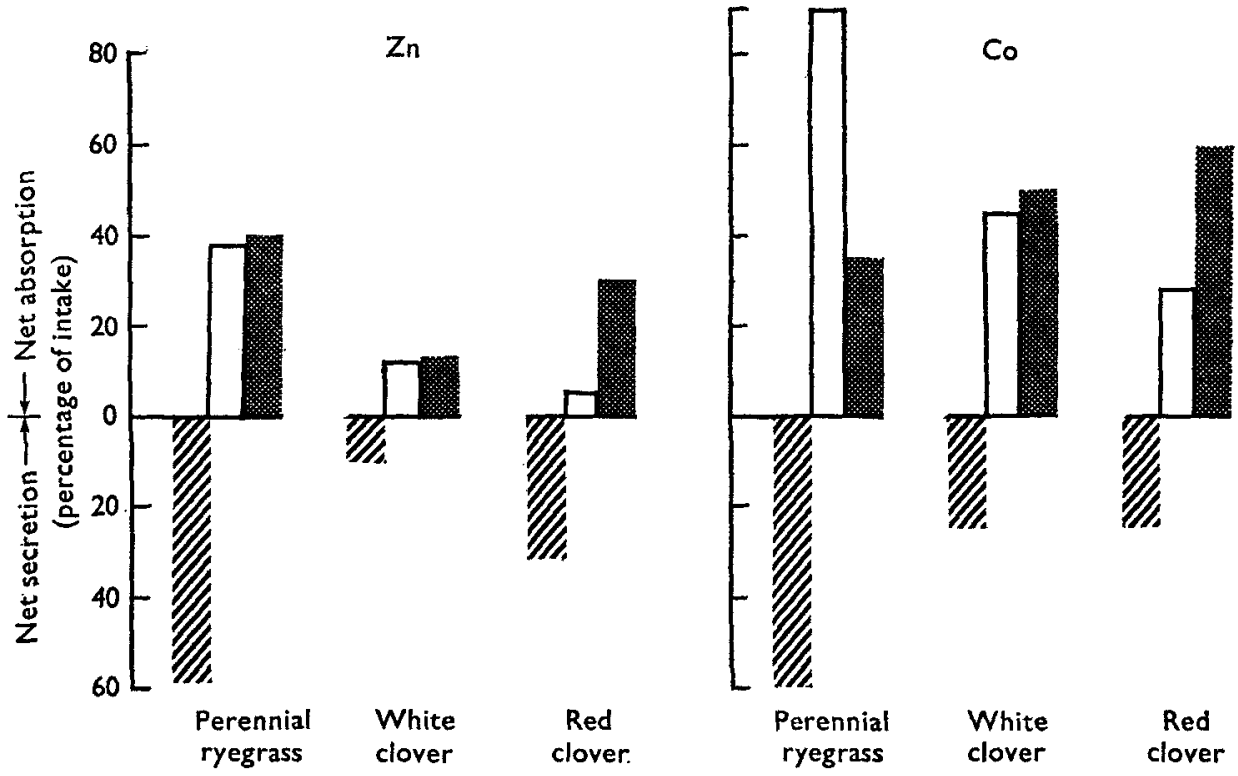

cu

Mn
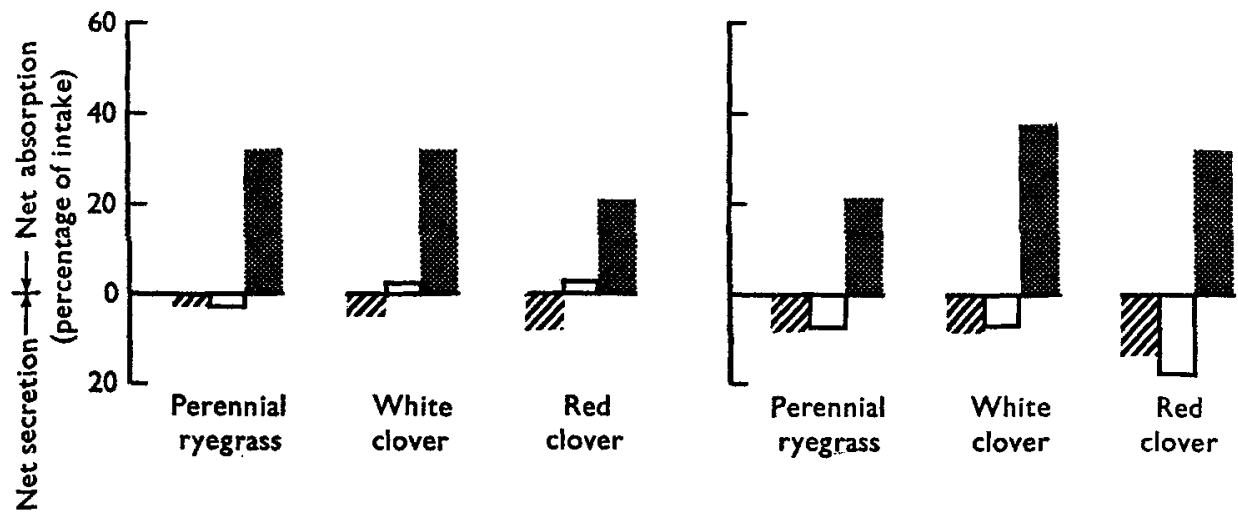

White

Red

Perennial

White

Red

clover

ryegrass

clover

clover

Fig. I. The sites of net secretion and net absorption of zinc, cobalt, copper and manganese, as determined from their flows along the digestive tract (amounts for each micro-element expressed as a percentage of intake), for sheep given fresh perennial ryegrass, white clover or red clover. Eight sheep received each of the diets during the 9-month experimental period (for details of experimental design, see Table I); four sheep were fitted with duodenal reentrant cannulas ( $50 \mathrm{~mm}$ beyond the pylorus) and four sheep were fitted with ileal re-entrant cannulas (400-500 $\mathrm{mm}$ from the ileo-caecal valve). $\square$, Stomach; $\square$, small intestine; 国, large intestine.

The results of the balance experiment (Table 3 ) indicated that there was a positive apparent retention of $\mathrm{Co}, \mathrm{Cu}$ and $\mathrm{Mn}$ for all sheep, and of $\mathrm{Zn}$ for sheep given perennial ryegrass or white clover. The apparent availability of Co was high (average value for the three diets $67 \%$ ) compared with that for $\mathrm{Zn}$ and for $\mathrm{Mn}$ (less than $15 \%$ ). The apparent availability of $\mathrm{Cu}$ was 30 and $36 \%$ for perennial ryegrass and white clover respectively and $9 \%$ for red clover. Except for $\mathrm{Co}$, the faeces were the main pathway 
for the excretion of the micro-elements, as the faecal losses relative to intake ranged from 66 to $97 \%$, and urinary losses were less than $8 \%$. The losses of Co in the faeces and urine were similar $(26-35 \%$ of intake).

\section{DISCUSSION}

The amounts of $\mathrm{Zn}, \mathrm{Cu}$ and $\mathrm{Mn}$ found in perennial ryegrass, white clover and red clover were similar to those previously reported (Fleming, 1965). The high values obtained for Co reflect some soil contamination (less than $\mathrm{I} \cdot 5 \%$ ) of the plant material during harvesting. However, in this study the Co contribution from the soil cannot be regarded as a contaminant. Under New Zealand farming conditions the grazing sheep can ingest more than $25 \mathrm{~kg}$ soil annually (Healy, 1972), and Rigg \& Askew (1934) have reported that soil Co is available to the sheep; the oral administration of soil to animals given $\mathrm{Co}$-deficient diets was found to prevent bush sickness. Although the availability of the $\mathrm{Co}$ in the soil ingested during this study was unknown, about $80 \%$ of the total Co intake was of plant origin. The $\mathrm{Cr}_{2} \mathrm{O}_{3}$-impregnated paper did contain trace amounts of $\mathrm{Zn}, \mathrm{Co}, \mathrm{Cu}$ and $\mathrm{Mn}$ but when these were compared with the dietary intakes the contamination from this source was less than $0.5 \%$ for $\mathrm{Zn}$, Co and $\mathrm{Cu}$, and less than $\mathrm{I} \%$ for $\mathrm{Mn}$.

The assumptions made, and the validity of using a marker to correct the values obtained for flow rates of digesta to mean $24 \mathrm{~h}$ flows, has been discussed fully elsewhere (MacRae \& Armstrong, 1969; Grace \& MacRae, 1972; Ulyatt \& MacRae, 1974). Also, for most micro-elements, the net absorption or net secretion is represented by a small difference between the quantities entering and leaving the region under study, but in the instance of the dietary organic constituents which are readily digested, a net or apparent absorption is represented by a large difference between the quantities entering and leaving the absorptive region. The approach in this study was therefore to make a large number of measurements (three diets, twelve-sixteen collections/diet) for the flow of $\mathrm{Zn}, \mathrm{Co}, \mathrm{Cu}$ and $\mathrm{Mn}$ along the digestive tract, and, therefore, obtain reasonable estimates of the net movements of these elements across the wall of the digestive tract.

Diet was not found to influence the pattern for the net movements of the microelements across the walls of the digestive tract. A net secretion of $\mathrm{Zn}$ and $\mathrm{Co}$ into the stomach region was found. Although for $\mathrm{Co}$ there have been no previous reports of secretion, for $\mathrm{Zn}$ there have been reported secretion into the rumen, the transfer taking place through the rumen epithelium (Watson \& Kastelic, 1967 ) as well as in the saliva (Hiers, Miller \& Blackmon, I968). Net absorption of $\mathrm{Zn}$ and $\mathrm{Co}$ took place from the small intestine. This is in agreement with the results of earlier studies of Hiers et al. (1968) for $\mathrm{Zn}$, and of Hedrich, Elliot \& Lowe (1973) for cyanocobalamin or $\mathrm{Co}$, as considerable quantities of dietary $\mathrm{Co}$ are used in the synthesis of cyanocobalamin (Hedrich et al. 1973). As considerable quantities of $\mathrm{Cu}$ (Van Ravesteyn, 1944) and $\mathrm{Mn}$ enter the small intestine in the bile, as well as through the intestinal wall in the instance of Mn (Bertinchamps, Miller \& Cotzias, 1966), it is suggested that in this study the quantities of $\mathrm{Cu}$ and $\mathrm{Mn}$ entering the small intestine in various endo- 
genous secretions may have been similar to the amounts being absorbed and therefore a significant net absorption of $\mathrm{Cu}$ and $\mathrm{Mn}$ would not have been found. In view of this it is interesting that in man it has been reported that of the $2-5 \mathrm{mg} \mathrm{Cu}$ ingested, $0.6-1 \cdot 6 \mathrm{mg}$ is absorbed while $0.5-\mathrm{I} \cdot 3 \mathrm{mg}$ is excreted in the bile (Cartwright \& Wintrobe, r 964 ). Further, since $\mathrm{Zn}$ is secreted into the small intestine in the pancreatic juice, bile and other secretions (Sheline, Chaikoff, Jones \& Montomery, r943; Pekas, r966), the actual absorption of $\mathrm{Zn}$ from the small intestine would be greater than the net absorption found in this study.

Although it could be concluded from the results of earlier studies, mainly with simple-stomached animals, that the small intestine was the main site of absorption and endogenous secretion of the micro-elements (O'Dell \& Campbell, 1970), in the present study a considerable net absorption of $\mathrm{Zn}, \mathrm{Co}, \mathrm{Cu}$ and $\mathrm{Mn}$ was found to take place in the large intestine. While it is well documented that the absorption of water and minerals, particularly sodium (Kay \& Pfeffer, 1970), takes place in the large intestine, further studies will be required to substantiate the above findings.

As previously reported (Underwood, I97I), it was also found that most (66-97\%) of the ingested $\mathrm{Zn}, \mathrm{Cu}$ and $\mathrm{Mn}$ was excreted in the faeces with small amounts (less than $8 \%$ ) being excreted in the urine of sheep. However, in the instance of Co about equal quantities were excreted in the faeces and urine. This is in contrast to the results of Comar, Davis \& Taylor (I946) with cattle, where most of the Co was found to be excreted in the faeces. In humans the main pathway for Co excretion is not clear: Harp \& Scoular (1952) found that for women most of the Co was excreted in the urine but for girls, Engel, Price \& Miller (1967) found that the faeces were more important than the urine as a pathway for Co excretion. The apparent availability, which is the net absorption of the element from the digestive tract expressed as a percentage of the intake, may give only limited information about the extent of the net absorption or net secretion of some micro-elements within various regions. For example, in this study, a considerable net secretion of $\mathrm{Zn}$ and $\mathrm{Co}$ into the stomach region was followed by a greater net absorption from the intestine region and therefore the quantities of the above micro-elements moving across the wall of the digestive tract were far greater than was reflected by the apparent availability or total net absorption from the digestive tract.

The author wishes to thank Dr P. L. Allen, Messrs A. S. D. King, B. S. Henderson, I. D. Shelton and K. Millard, and Mrs E. Davies for technical assistance, and Dr W. B. Healy for doing the plant and soil titanium determinations.

\section{REFEREN CES}

Beever, R. E., Thomson, D. J., Pfeffer, E. \& Armstrong, D. G. (1971). Br. Y. Nutr. 26, r23.

Bertinchamps, A. J., Miller, S. T. \& Cotzias, G. C. (1966). Am. F. Physiol. 2rr, 217.

Brown, G. F., Armstrong, D. G. \& MacRae, J. C. (1968). Br. vet. F. 124, 78.

Cartwright, G. E. \& Wintrobe, M. M. (1964). Am.F. clin. Nutr. 14, 224.

Comar, C. L., Davis, G. K. \& Taylor, R. F. (1946). Archs Biochem. 9, 149.

Engel, R. W., Price, N. O. \& Miller, R. F. (1967). F. Nutr. 92, 197.

Field, A. C. \& Purves, D. (1964). Proc. Nutr. Soc. 23, xxiv.

Fleming, G. A. (1965). Outl. Agric. 4, 270. 
Grace, N. D. \& MacRae, J. C. (1972). Br. F. Nutr. 27, 51 .

Harp, M. J. \& Scoular, F. I. (1952). F. Nutr. 47, 67.

Healy, W. B. (1968). N.Z. Yl agric. Res. 11, 487.

Healy, W. B. (1972). Proc. N.Z. Grassld Ass. 34, 84 .

Hedrich, M. F., Elliot, J. M. \& Lowe, J. E. (1973). F. Nutr. 103, 1646.

Hiers, J. M., Miller, W. J. \& Blackmon, D. M. (r968). J. Dairy Sci. 5r, 730.

Kay, R. N. B. \& Pfeffer, E. (1970). In Physiology of Digestion and Metabolism in the Ruminant, p. 390 [A. T. Phillipson, editor]. Newcastle upon Tyne: Oriel Press.

MacRae, J. C. \& Armstrong, D. G. (1969). Br. J. Nutr. 23, I5.

O'Dell, B. L. \& Campbell, B. J. (I970). In Comprehensive Biochemistry, vol. 21, p. I79 [M. Florkin and E. H. Stotz, editors]. Amsterdam: Elsevier Publishing Company.

Pekas, J. C. (1966). Am. F. Physiol. 2r1, 407.

Perkin-Elmer (1971). Analytical Methods for Atomic Absorption Spectrophotometry. Norwalk, Connecticut: Perkin-Elmer.

Rigg, T. \& Askew, H. O. (1934). Emp. F. exp. Agric. 2, I.

Sheline, G. E., Chaikoff, I. L., Jones, H. B. \& Montgomery, M. L. (r943). J. biol. Chem. I47, 409.

Ulyatt, M. J. \& MacRae, J. C. (r974). F. agric. Sci., Camb. 82, 295.

Underwood, E. J. (197r). Trace Elements in Human and Animal Nutrition, 3rd ed. New York and London: Academic Press.

Van Ravesteyn, A. H. (1944). Acta med. scand. I18, I63.

Watson, R. H. \& Kastelic, J. (r967). Aust.F. biol. Sci. 20, 975.

Williams, C. H., David, D. J. \& Iismaa, O. (I962). J. agric. Sci., Camb. 59, 381. 